Seton Hall University

From the SelectedWorks of Karen Bloom Gevirtz

Spring 2003

\title{
Ladies Reading and Writing: Eighteenth-Century Women Writers and the Gendering of Critical Discourse
}

Karen Gevirtz, Seton Hall University 


\section{Modern Language Studies}

Ladies Reading and Writing: Eighteenth-Century Women Writers and the Gendering of Critical Discourse

Author(s): Karen Bloom Gevirtz

Reviewed work(s):

Source: Modern Language Studies, Vol. 33, No. 1/2 (Spring - Autumn, 2003), pp. 60-72

Published by: Modern Language Studies

Stable URL: http://www.jstor.org/stable/3195308

Accessed: 08/08/2012 09:30

Your use of the JSTOR archive indicates your acceptance of the Terms \& Conditions of Use, available at http://www.jstor.org/page/info/about/policies/terms.jsp

JSTOR is a not-for-profit service that helps scholars, researchers, and students discover, use, and build upon a wide range of content in a trusted digital archive. We use information technology and tools to increase productivity and facilitate new forms of scholarship. For more information about JSTOR, please contact support@jstor.org. 


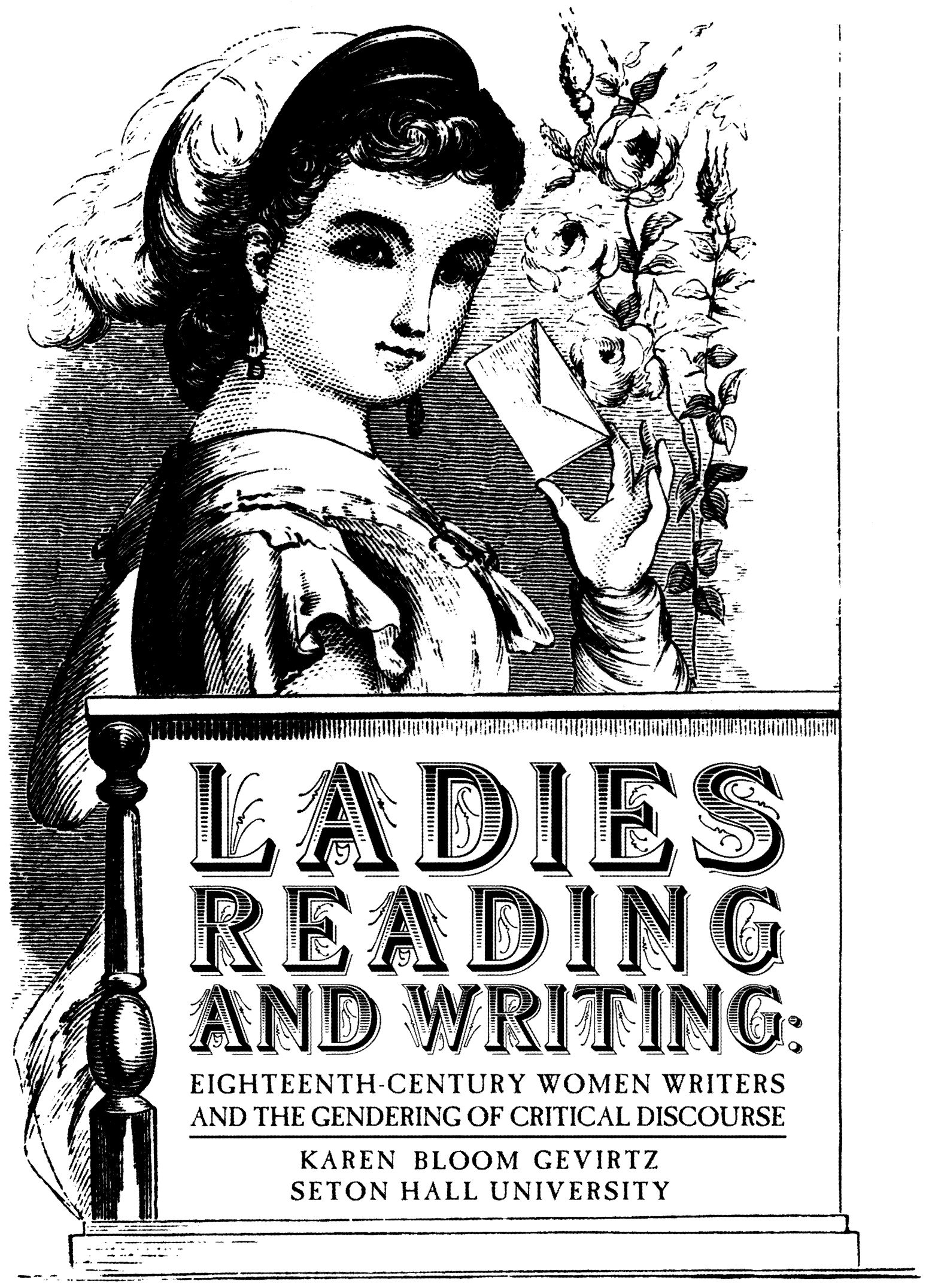




\section{And there is scarce a Poet, that our English tongue boasts of, who is more the Subject of the Ladies Reading.}

LEWIS Theobald, ShaKespeare Restored

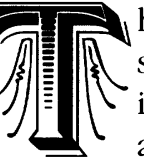
he canon of eighteenth-century Shakespeare critics includes some of the luminaries of the age, including Samuel Johnson and Alexander Pope, but it includes far fewer female critics. Nevertheless, as recovery efforts in the last thirty years have shown, women not only numbered among eighteenth-century readers of Shakespeare, but also among eighteenth-century writers about Shakespeare. Charlotte Lennox's Shakespear Illustrated (1753), Elizabeth Montagu's Essay on the Genius of Shakespeare (1769), and Elizabeth Griffith's The Morality of Shakespeare's Drama Illustrated (1775) all appeared during Shakespeare's triumphant rise to mass popularity, and they exemplify both the ideas and methods of their time as vividly as the more famous criticism of their male peers. Nevertheless, these works did not achieve success similar to the male-authored texts which they resembled. A comparison of their technique and attitudes to their critical and commercial success during the eighteenth century reveals that their success inversely correlates with the degree to which these texts used the dominant literary strategies of Shakespeare criticism of the period. This correlation suggests that discursive techniques acceptable in the works of men were not as acceptable in the works of women, even when those same women authors produced highly successful narrative fiction with equally critical bents. This study of these three works of Shakespeare criticism thus suggests a reason for the difficulty in finding conventional criticism by women, and supports recent proposals for reading the female-authored novel as a vehicle for female-authored criticism.

It is no longer a question whether women were writing criticism, although the number of currentlyknown female Shakespeare critics is certainly small. What happened to make such women vanish from our understanding of the period for so long does remain an issue, as does the recognition of their particular contributions to different critical discourses. As a group, the publication record of these three eighteenth-century female Shakespeare critics indicates that they achieved mixed success during the period. Charlotte Lennox's 1753 Shakespear Illustrated earned a tepid response at the time of publication. The two reviews that appeared in the Gentleman's Magazine were both favorable and both authored by Samuel Johnson, and it sold well enough to warrant a third volume in the following year, but it never made it to a second edition or to any foreign language editions. By decade's end, Shakespear Illustrated had fallen into obscurity.

Later female critics encountered relatively greater success. Elizabeth Griffith's The Morality of Shakespeare's Drama Illustrated (1775) garnered more critical and popular acclaim, but like Shakespear Illustrated, it did not achieve significance or longevity. The Critical Review called Griffith "ingenious" and her insights "judicious," but the reviewer did not seem to have read past the first essay (Rev. of Morality, Critical Review 203, 204). The Monthly Review announced that "Mrs. Griffith has performed a very acceptable service to the Public" and calmly recommended her "book of moral and oeconomical instruction" to "general use, especially to young persons" (Rev. of Morality, Montbly Review 466). Griffith's work disappeared from critical and popular consciousness after the second edition was published in 1777. Of the three, Elizabeth Montagu did the best with her 1769 Essay on the Writings and Genius of Shakespeare. It was generally approved and the Critical Review announced that "The age has scarcely produced a more fair, judicious and classical performance of its kind than the Essay"' (Busse 69). Sir Joshua Reynolds liked it; so did David Garrick, James Beattie, and James Harris (Busse 41-42; Smith xxin). It went to five editions in Montagu's lifetime and a sixth after her death. Italian and French editions also appeared in 1776 (Busse 73). Nevertheless, after that sixth edition it did not appear in print again and essentially has vanished from discussions of eighteenth-century Shakespeare criticism.

It was not the ideas propounded by female crit- 
ics that resulted in these dismissals. Eighteenth-century male and female critics did not differ significantly in their views about Shakespeare; in fact, men and women held many of the same views about the Bard and his work. During the early 1750s, when Charlotte Lennox was writing Shakespear Illustrated, commentators on Shakespeare were still debating the playwright's merits. The debate had begun in the mid-seventeenth century, when Margaret Cavendish championed Shakespeare against the criticism of her friends and others in her Sociable Letters (129-131) ${ }^{1}$ Eliza Haywood complains in The Female Spectator (1745) that Shakespeare's comedies and tragedies could "be compared to fine Gardens full of the most beautiful Flowers but choaked up with Weeds through the too great Richness of the Soil." She not only prefers Otway's abridgment of Romeo and Juliet to the original version, but also argues that Otway did not cut enough (163). Those proclaiming the Bard's virtues felt the need to do so defensively. Peter Whalley's An Enquiry into the Learning of Shakespeare (1748) refutes the critical contingent belittling the playwright for a lack of education, and Joseph Warton's five Adventurer essays (1753-1754) insist upon Shakespeare's talents in depicting human nature. Even the academic community was still learning to embrace Shakespeare: the first university lectures on the Bard did not take place until the 1750s (Binns 20). Hence, although Charlotte Lennox's skeptical approach in Shakespear Illustrat$e d$ was more acerbic than the time usually produced, it was also generally consistent with an atmosphere that still allowed negative assessments of Shakespeare's drama.

Conversely, by the time that Montagu and Griffith composed their works in the 1760s and 1770s, it was nearly impossible to write other than admiringly of Shakespeare and his productions. ${ }^{2}$ Shakespeare's popularity with audiences of all kinds had grown throughout the period, encouraged by a combination of popular pressure, cultural nationalism, and increasing access to scholarly editions. The price of a ticket brought even the lower classes to performances of Shakespeare's plays. University audiences could listen to some of the century's best minds, including Adam Smith, lecture on Shakespeare and his work. By 1767, two-thirds of the copyright to Shakespeare's plays was worth 1200 at auction and nationalist fervor was inseparable from Bardolatry (Belanger 18; Small 205). Montagu's Essay on the Writings and Genius of Shakespeare furiously refuted Voltaire's scathing rejection of Shakespeare's plays and Griffith's The Morality of Shakespeare's Drama Illustrated reinforced Montagu's Essay. Both women joined the discussion of Shakespeare by toeing the party line. Overall, whether skeptical of Shakespeare's talents or awestruck by them, female critics did not differ in opinion with the male critics of their time. It is not on the basis of their ideas, then, that these works by these three women were dismissed.

Nor was the disappearance of their criticism a result of a lack of literary talent. A look at their other writing reveals competent authors at the very least, and certainly women who knew good from bad when it came to literature. Montagu's contributions to Lyttelton's philosophical narratives, Dialogues of the Dead, were well-received in certain circles. Elizabeth Griffith had a fine literary career as a novelist and playwright. ${ }^{3}$ Charlotte Lennox wrote several successful novels, including The Female Quixote. Positive reviews of this novel appeared in the popular press from notables such as Samuel Johnson and Samuel Richardson; Henry Fielding even compared it favorably to its predecessor, Cervantes' Don Quixote (Levin 279-280; Small 2, 13; Fielding 160-161). The work sold well and made Lennox's literary reputation.

Significantly, The Female Quixote's audience readily applauded it as a critical work. Fielding recognizes that like Don Quixote, The Female Quixote aimed at "not only the Diversion, but the Instruction and Reformation" of readers, especially "young Ladies," and he notes that Lennox displays "all those Vices and Follies in her Sex which are chiefly predominant in our Days" (Fielding 159, 161). Fielding's review articulates an idea familiar to eighteenth-century readers and writers alike: that narrative, including narrative fiction, could be a vehicle for critical ideas. Critics like Henry Fielding and especially Shakespeare's critics understood narrative and criti- 
cism as intersecting, mutually reinforcing discourses. As Maurice Morgann puts it in "An Essay on the Dramatic Character of Sir John Falstaff" (1777), "The argument itself, like the tales of our Novelists, is a vebicle only; theirs, as they profess, of moral instruction; and mine of critical amusement" (225).

Eighteenth-century Shakespeare criticism employed devices both from what we have come to consider narrative and from what we have come to consider discourse, that is, critical prose. Peter Whalley's Enquiry into the Learning of Shakespeare, for example, is a dialogue. Male and female critics also wrote their criticism as if speaking to someone, often addressing a "reader" or a specific person and employing a lively dialogic voice. Whalley's dialogue opens with an apology to "the Reader" for his work (vii), but this address could be aggressive as well as apologetic. "There, you read it," Lewis Theobald announces amidst a sea of "I"s and "we"s meant to force the reader to accept Theobald's assumptions as his or her own (97). This self-consciousness appears most famously in Laurence Sterne's Tristram Shandy, on which eighteenth-century Shakespeare critics drew. "Shades of Burgersdicius!" exclaims Richard Farmer at one point in his 1767 "Essay on the Learning of Shakespeare" (152), and Morgann complains that he "cannot foresee the temper of the reader, nor whether he be content to go along with me in these kind of observations," later mentioning Tristram Shandy directly (230, 274). Griffith also relies on Sterne from time to time, observing for instance that "Sterne's comparison of the jester and the jestee, to the mortgager and mortgagee is an excellent and just allusion" (96).

This understanding of narrative and criticism's ability to overlap is significant for a number of reasons. Historically, it yielded criticism with a high narrative content. Morgann weaves examples from and allusions to novels into the commentary, such as when he approves Candide or mentions "the History of Miss Betsy," the "Story of Miss Lucy," and the "tale of Mr. Twankum" (253). Griffith draws on the epistolary narrative Letters between Henry and Frances to support her argument (453). Joseph Warton merges recapitulations of plot with descrip- tions of the plays' beauties because, he argues, "GENERAL criticism is on all subjects useless and unentertaining; but is more than commonly absurd with respect to SHAKESPEARE, who must be accompanied step by step, and scene by scene, in his gradual developements [sic] of characters and passions, and whose final features must be singly pointed out, if we would do compleat justice to his genuine beauties" (II: 276). Critics throughout the century hung evaluations of the plays upon their dramatic events. Writing on The Tempest, Griffith explains that "Prospero, having thus got his enemies within his power, on their repentance, generously forgives them their cruelty and injustice, recovers his dukedom once again, and the marriage of the lovers confirms an alliance on both sides" (3). Throughout The Morality of Shakespeare's Plays, she gives the background and events of the play before examining moral moments chronologically, commenting as she goes. Even if she omits the "Fable," which she does when she can find no moral in the plot, she still uses the events of the play to shape her criticism.

Less generous sentiments found expression in restating the play's events, as well. According to Theobald, "Polonius, (an officious, impertinent old Courtier,) priding himself in the Discovery which he supposes he has made of the Cause of HAMLET's Madness, is so full of the Merit of it, that he can't content himself to deliver it in a plain and easy Manner, but falls into an affected jingling Sort of Oratory" (64). Even the generally gentle Montagu uses tart retellings to express opinion. "Galba addresses to his niece, who is in love with Otho, the fine speech which the historian supposes him to have made to Piso when he adopted him," she explains. "The lovesick lady, tired of an harangue, the purport of which is unfavorable to her love, and being besides no politician, answers the emperor, that she does not understand state affairs," and she continues in this vein for some time (Montagu 63-64). Although Montagu applies narrative for critical purposes to Corneille's plays, which Voltaire elevated above Shakespeare's, the technique is the same. The retelling of the play serves as a critical vehicle for the author. 
This mocking narration of dramatic events was honed razor-sharp by Lennox in Shakespear Illustrated, where she used narrative sections primarily to express disbelief and contempt. In her hands the original sources for Shakespeare's plots appear with all the accoutrements of entertainment, including dialogue and an omniscient narrator who allows the story to progress without comment, thereby tacitly endorsing it. Recounting the story in the source for Measure for Measure, Lennox includes Lodovico's (Claudio's) long speech to his sister Epitia (Isabella), in which he declares, "I have erred I confess; you by your superior Wisdom may correct my Errors" (I: 10). Shakespeare's stories, however, are only summaries, usually presented without even quotations from the play. For the same scene in Measure for Measure, Lennox merely reports that Isabella "goes to the Prison and acquaints Claudio with her ill Success; the Youth, fond of Life, intreats her to save him, and comply with the Deputy's Request: She, after reproaching him severely for his Baseness, quits him in great Rage" (I: 22). By abridging the story, Lennox implies that it does not have sufficient merit to warrant or even to enable the extensive narrative of the original source.

Like other critics such as Theobald, Lennox also uses characterization to express opinions. Adjectives, for example, indicate a judgment: "the stupid Son of his second Wife," "a ridiculous dispute," "the counterfeit Friar" (I: 156, I: 157, I: 23). Sometimes the commentary is more overt, particularly in descriptions of an episode. "The injured Princess, however," Lennox reports, "is impatient to be on Horseback, she whips out of the Palace in a Minute, and passes invisibly, we cannot help supposing, though there is no Inchantment in the Case, though the midst of her Attendants and Guards, and gallops away to meet her Husband" (I: 161). The low diction-"whips," "in a Minute"-combines with the incredulous tone-"we cannot help supposing," "passes invisibly" - to undermine the acceptability of this part of Cymbeline. Female critics, like male critics, thus employ narrative devices to evaluate Shakespeare's plays and consequently to evaluate the cultural assumptions of value attached to them.
The use of narrative, therefore, is not what tripped up Shakespeare's female critics. Rather, it was discourse that did them in. The more closely female critics adhered to criticism's discursive conventions, the more forceful their critical and commercial rejection. It is more than a question of authorial gender; it is also that gender's relationship with a given literary form. Susan Sniader Lanser points out that the use of literary convention is not simply an authorial choice. It is a part of a dynamic among authors, audiences, and texts "produced in and by the relations of power" that governs these entities' connection, a "conjunction," as Lanser puts it, "of social and rhetorical properties" $(6,5)$. As a result of these "relations of power," women and men do not always use the same literary devices to achieve the same literary affects, because, Lanser argues, not all "forms of voice have been available to women" at any given historical moment (15). In particular, critical discourse, according to Lanser and Evelyn Torton Beck, maintains a traditional vocabulary involving an "underlying ethos of power, battle, possession, and control" inappropriate to women critics' conception of their task, which is about "illumination, co-creation, and partnership" (Lanser and Beck 86-97). This vocabulary of conquest and possession keeps women out of genres traditionally associated with criticism and theory. ${ }^{4}$ From a more historical perspective, Laura Runge's examination of eighteenth-century female critics reveals that women developed a variety of strategies for coping with changing pressures in the critical marketplace, which included the difficulty of reconciling the mid-century "version of femininity" with criticism's "fundamental activities of learning and judgment" (Runge 122).

In the case of eighteenth-century Shakespeare criticism it was the independent, authorial stance requisite for Shakespeare critics that was the sticking point for these female authors. Ellen Gardiner points out that women could establish "powerful authorial subjectivities as critics" (148). Nevertheless, the authorial stance in Shakespeare criticism, which signaled the credibility of the ideas contained within the text, proved problematic for female authors. As Simon Jarvis notes, Shakespeare's eigh- 
teenth-century editors had to balance not just "intellectual labor" itself but their representation as editors in the text (15). Further complicating this need to do the work and to represent it in certain ways is the position of the author of Shakespeare criticism, which not only indicated a larger, ideological understanding of what Shakespeare criticism was supposed to accomplish, but also changed over time. According to Marcus Walsh, the conventional critical stance shifted from a seventeenth-century emphasis on the editor's aesthetic sensibility to an eighteenth-century emphasis on the author's meaning, uncovered or revealed by the perceptive but secondarily-important editor (23). This "authorial orientation," as Walsh calls it, is not without the "responsibility of interpretive judgment," however, so although the editor ostensibly engages in "an attempt to reconstruct the author's intended reading," he or she also engages in an attempt to present his opinion of the author's intent. That means that the presentation of the commentator's own authority is crucial to the success of the otherwise seemingly objective criticism: as Walsh notes, eighteenth-century editors in particular made decisions that "constantly emerged out of, and were the subject of, interpretive discussion" $(15,16,23-24)$.

The commercial elements of Shakespeare criticism also contributed to the need for an authoritative authorial stance. The role of editing in the eighteenth century's creation of "the Bard" cannot be overstated. Because editions ranged greatly in cost and were therefore affordable to a variety of classes, the aesthetic promoted by any given editor, not to mention the celebratory aesthetic created by the sheer number of editors, reached an increasingly sizable population (Dash 268; Franklin, Shakespeare Domesticated 26). The choices as well as the commentary in these texts greatly contributed to the perception of the Bard, since editing decisions shape a text and consequently influence its interpretation and valuation by the reader. Control of the edition therefore was inextricably linked not simply with an interpretation of the text at hand, but with an interpretation of the author's cultural position, an interpretation made more credible, as Jarvis and
Walsh point out, by the demonstration of the editors' acumen. Eighteenth-century critics were very aware of this relationship between editing and valuing: as Lewis Theobald puts it, "I have always thought, that whenever a Gentleman and a Scholar turns Editor of any Book, he at the same Time commences Critick upon his Author" (v).

Women as well as men understood the importance of creating an authoritative stance for presenting their ideas, and how the demonstration of critical acumen and the competition to present authoritative commentary became increasingly central to the work of Shakespeare criticism. At the most basic level, male and female authors ostentatiously display their educational credentials. They allude to classical mythology and show off their linguistic abilities, casually interjecting phrases in foreign languages both ancient and modern. Montagu uses French and Latin; Theobald uses Latin, Greek, and Anglo-Saxon. Lennox clubs other critics with her fluency in Italian. In one instance she points out that "Cintbio calls her a Cittadina, which Mr. Rymer translates a simple Citizen; but the Italians by that Phrase mean a Woman of Quality" (I: 132). She follows this observation with an entire paragraph of examples of correctly translated Italian class-names to underscore Rymer's ineptitude (I: 132).

Intellectual prowess was as important as linguistic prowess. "It is not to be doubted but Shakespear followed Hollingshed in the Facts which compose this Play, as well as in many of his other historical Plays," Lennox notes with assurance. "In the History of Macbeth, where he found Hollingshed's Chronicle deficient, he probably consulted Bellendon, who translated Boetius in 1541" (I: 273). Montagu's sources include Voltaire, Homer, Sir Thomas More, Corneille, Boileau, Euripides, Lucan, Horace, Aeschylus, Alexander Pope, and Aristotle. In one paragraph alone, Farmer quotes or mentions Drayton, Digges, Suckling, Denham, Milton, and Dryden (156). Critics also demonstrated familiarity with contemporary discussions of significant issues such as sympathy and sentiment, the role of morality in literature, or the Aristotelian unities in drama. Morgann even puts a monologue praising Shakespeare into 
Aristotle's mouth to emphasize Shakespeare's value according to hallowed Aristotelian principles (235).

Men and women also use the same variety of pronouns to establish command over the audience that characterizes much analytical and argumentative writing. Moving among the first-person singular, the collective first-person plural, occasional direct addresses the reader, and an Olympian third-person singular that evokes a sense of omniscience, male and female authors create the same sense of authority. And, like the men, Lennox, Montagu, and Griffith refer to Shakespeare as "our Author" or "our Poet," suggesting that claims to Shakespeare transcend gender in their nationalism (Warton II: 308; Montagu vi).

Women also assumed the oppositional stance characteristic of male-authored Shakespeare criticism. The need to position one's own text's authority as supreme resulted in a variety of critical relationships between the author of any given text and all other Shakespeare critics. Establishing a position within the community that involved the mutual recognition of the author and other critics contributed to a posture of authority, and male and female critics used a range of tones, occasionally even polite ones, to describe their colleagues. Although such veneration can indicate a literary submission of women to men, in Shakespeare criticism this posture becomes a convention used to express civility between critics, regardless of gender. Farmer supports Thomas Hanmer over Samuel Johnson only to conclude, "Sir Thomas Hanmer is right; yet it is no argument for his Author's Italian knowledge" (195). Warton compliments Pope's sylphs in The Rape of the Lock, but adds that because Pope had read The Tempest, they are ultimately only derivative, and Theobald, who consistently prefers Hughs's readings over Pope's, still "wonder[s that] Mr. $H U G H S$, who inserted this Passage in his Impression, and could not but see that something was wanting, did not at the same time endeavour to supply it" (Warton II: 136; Theobald 107-108). Montagu's Essay opens with a favorable discussion of Alexander Pope's preface to his edition of Shakespeare and continues by acknowledging "some of the most learned and ingenious of our critics" and their "cor- rect editions of his works," produced by a "superiority of talents and learning" to her own (v). Her deft assumption that all the editions are "correct" allows her to compliment her male colleagues and sidestep the critical disagreements predating her Essay, thus avoiding taking sides in the antagonistic world of Shakespeare scholarship.

General stances could give way to particular stances at any given moment in the criticism. In a discussion of Otbello, for example, Charlotte Lennox accepts Thomas Rymer's assessment that Shakespeare misreads human nature, but adds that Rymer omitted a character who supports this argument, Emilia (I: 129). Griffith opens her work with a sycophantic dedication to Garrick and occasionally contradicts other critics with great deference: "Doctor Warburton has changed were to are, because, he says, the expression, in the text, is false divinity." She "tremble[s] at venturing to differ from so learned a judge in matters of theology" but wonders if there is a possible alternative understanding (39-40n).

Griffith's ability to disagree with Warburton indicates an even more important aspect to creating authority for a text: the distinction of opinion from other critics' that makes one's own work original and valuable. Her differing from Warburton in matters of theology and interpretation exemplifies a quiet affirmation of her own authority; when she uses Johnson's reading, for example, she adds that the "context of the speech vouches the propriety of the alteration" (134n), validating his judgment with her own, rather than vice-versa. This ultimate assertion of the author's opinion over any others is related to the more famous vein of Shakespeare criticism, antipathy. Shakespeare scholars did not necessarily grant each other equal legitimacy and their attacks on each other, particularly on the basis of scholarly training, are well known. ${ }^{5}$ Nicholas Rowe explains that "As I have not propos'd to my self to enter into a Large and Compleat Criticism upon Mr. Shakespeare's Works, so I suppose it will neither be expected that I should take notice of severe Remarks that have formerly been made upon him by Mr. Rbymer." Nevertheless, he continues, "I must confess, I can't very well see what could be the Reason 
of his animadverting with so much Sharpness" (9). In case his title did not reveal his opinion of Pope's edition, Theobald hastens to eviscerate the poet, announcing of an early fault that "it is a Specimen only of the epidemical Corruption, if I may be allowed to use that Phrase, which runs thro' all the work" (vii). This aggressive, self-aggrandizing rhetoric crosses gender lines. Griffith's totalizing strategies sometimes give way to a more precise targeting mechanism: "The only editor who has taken notice of [a phrase], is Theobald; but his comment is as obscure as the text" (320n). Usually conciliating with other critics, Montagu lavishes hard words on Voltaire, who had denigrated Shakespeare. Although she does credit him for his acceptable views- "Mr. Voltaire has the candour to own, this is a bad Tragedy" (21) she has much more to say on his poor judgment in particular and on French taste, culture, and theater in general. "Fine dialogues of love, interwoven with a tale of incest and murder, would not have been endured in any country, where taste had not been absolutely perverted," she insists (21).

Sometimes authors allude to another author contemptuously and without the courtesy of a name. Johnson often mentions judgments by nameless and incorrect "commentator"s or "editor"s, and Maurice Morgann applies the same technique in his defense of Falstaff. Similarly, Griffith alludes to "Editors" or "Commentators" only to insult and criticize: "The Commentators are all dumb upon this fine passage-not silent in admiration, but frozen into scholastic apathy. One may say of such cold critics on Shakespeare, what Addison does of lukewarm Christians" (481). Anyone who has not read the material will not know who these unnamed critics are, but anyone who has will. As an obscuring method, imposed anonymity thus appears in texts regardless of the gender of its employer or object.

While these strategies for establishing their authority served the male commentators well, they proved counter productive for the women, who achieved greater success the more they eschewed such displays of authority. Montagu restricts her hostility to a target across the Channel. Furthermore, Montagu's Essay makes it clear that she only takes up the argument after Voltaire has started it, thus offering her work as a nationalistic defense of a great cultural icon rather than a work of independent, intellectual acumen establishing a place by criticizing male, English scholars. She achieved the greatest commercial and critical approval of these female Shakespeare critics.

At the other end of the spectrum lies Lennox's work. Her Shakespear Illustrated is famous for its uncompromising critical egotism in asserting the justness of its own judgment and the reprehensibility of everyone else's, including Shakespeare's. Just as Rymer had suffered at Rowe's hands, so he suffers at hers, as she blasts his understanding of Italian (I: 132). Like Theobald before her, she too is merciless to Pope:

Mr. Pope, in his Preface to his Edition of Shakespear's Plays, tells us, that 'Shakespear's Characters are Nature herself; and that it is a Sort of Injury to call them by so distant a Name as Copies of her.'

It is certain, that all the Characters in Romeo, excepting, as I said before, $\mathrm{Mercu}$ tio's, are exact Copies of those in the Novelist; and since he copied them from the Translator, and not the Original, in this Instance Mr. Pope's Observation of other Authors, may be applied to Shakespear, that 'His Picture, like a mock Rainbow, is but a Reflexion of a Reflexion.' (I: 100)

Significantly, as this passage indicates, Lennox yokes the critique of the critics to a critique of William Shakespeare. If Rymer's language skills are execrable, for example, the Bard's are worse, and both are inferior to hers (I: 90, I: 99). Lennox thus demolishes her opponents' credibility and value while elevating her own standards, conclusions, and acumen. Her work vanished most quickly of the three.

Griffith's commentary balances between Montagu's conciliating and Lennox's witty and hostile tone as she presents not just her own aesthetic opinion about the beauties of the plays, but also her own editorial decisions about the words of the text. Scholars have suggested that Griffith's work demon- 
strates "ambivalence" about her critical project: uncomfortable with her own acumen and intimidated by Shakespeare's authority, Griffith nevertheless evinces a strange, almost frightened persistence in asserting herself (Argyros 285). Based on the tone, the engagement with critical conventions, and the placement of those conventions, I would suggest instead that Griffith's Morality demonstrates a careful negotiation between assertion and deference. She starts small. In the first essay of the volume, on The Tempest, Griffith writes that The Tempest and Midsummer Night's Dream are "generally supposed to have been the first and second of [Shakespeare's] writing" but, "if I may be allowed the liberty of a criticism about this matter, I should be rather inclined to suppose [The Tempest ] to have been one of his latter performances" (2). This comment is her only editorial opinion in the first three essays, but in her fourth essay, on Measure for Measure, she joins the fiercest fighting, the editorial battles, by making editorial decisions of her own. She frequently includes a suggestion from another critic: Johnson most often, Warburton a close second, and much more rarely, Theobald or Hanmer.

In addition, as the book progresses, Griffith offers her own adjustments to Shakespeare's texts, such as "The text word is bumility - I have ventured to change it to one that is more fitly opposed to tyranny" (100n). Ultimately, she makes her own suggestions and disagrees with other authorities. "The word, in the text, is valour," she explains, "but Theobald changes it to savour, in order to compleat the enumeration of the senses; and I prefer the word flavour, as this refers more to fruits, as the other to viands" (100n). Elsewhere she says of Titus Andronicus that Shakespeare's "stile and manner are so strongly marked, throughout this Play, . . that I own it surprizes me Doctor Johnson should say, 'he did not think Shakespeare's touches discernible in it" (406). In choosing to edit the plays, Griffith enters the center of power not simply of Shakespeare criticism, but of the effort to deify the playwright. The placement of almost all of her editorial efforts in the footnotes, and their commencement only after the first three essays, suggests her awareness of the power and danger of her gesture. Although the tone of her remarks is sure and sometimes combative, Griffith's notes appear in places where they could be overlooked and only after the author has seemingly established herself as a deferential member of the Shakespeare community. One wonders what the favorable reviewer in The Monthly Review might have said after encountering the editorial footnotes that begin in the fourth essay.

A more precise example of the resistance to women taking an authoritative, discursive stance appears in the reactions to two Shakespeare critics, Elizabeth Montagu and Charlotte Lennox. The success of Montagu's Essay depended on its relationship with men. The Essay first appeared anonymously, and its initial acceptance may have been made easier by its namelessness. Furthermore, when it did confess its authorship in a second edition, the work was probably helped by its rather glittering collection of male admirers and Montagu's almost maternal image as patroness of the arts. More significant, however, was its dialogue with a man, its intended target, Voltaire. Voltaire's response to Montagu's attack seems to have generated enough interest to sustain further editions. In March 1778, when the Essay was in its fourth edition, Voltaire presented one last critical letter to the Académie on the subject of Montagu and her views (Busse 71-73), but after the contest ended, the Essay went to only one more edition during her lifetime. Without the connection to Voltaire and British patriotism, critics evaluated her opinions and techniques on the basis of her gender and found them wanting. When Maurice Morgann alludes to it in his 1777 defense of Falstaff, he is "grieved to find" that "Mrs. MONTAGUE" [sic] is "involved in a popular error" of thinking Falstaff a coward. Although he acknowledges her "genius and virtues," he concludes that her mistake arises from the limitations of her sex and character: "your manners and your mind are yet more pure, more elegant than your book. Falstaff was too gross, too infirm, for your inspection" (252). Morgann thus dismisses Montagu's text not on the basis of skill but on the assumption of its gendered viewpoint. For Morgann, that Montagu disagreed with him could only be a result of an inferior under- 
standing based on her gender, rather than the disagreement of two critical minds.

Samuel Johnson's response to Lennox and Montagu further elucidates Morgann's position and more thoroughly demonstrates how historically, the perceived gendering of critical discourse caused the exclusion of female critics. After his lukewarm reviews in the press, Johnson's strongest reaction to Lennox's Shakespear Illustrated appears in the dedication to Lord Orrery. Although the Dedication prefaced Shakespear Illustrated under Lennox's name, it was actually composed by Johnson, who, as Jonathan Brody Kramnick points out, used the Dedication to contain Lennox's stance in the book itself. ${ }^{6}$ This attempt suggests that Lennox did not produce what Johnson wanted even though the scholarship is precisely what he seems to have asked for. In fact, Johnson evidently credited Richard Farmer with identifying where Shakespeare got his source material, although Farmer's 1767 "Essay on the Learning of Shakespeare" came out fifteen years after Lennox's three-volume set (Smith xxvii, xxviin). When it came to a positive opinion of Shakespeare, however, Johnson did not like a woman's work any better. He actively and intensely disliked Montagu's Essay (Busse 42). After scoffing at David Garrick for not contributing to the glorification of Shakespeare by writing criticism, Johnson replies to Boswell's observation that Montagu had praised Garrick with, "It is fit she should say so much, and I should say nothing" (Boswell 207, 207n, 208). A woman trying her hand at criticism, regardless of what she was saying, was evidently too much for Johnson, who had otherwise encouraged women such as Hester Thrale-whose work, a diary, was private-and Frances Burney-whose work was public but narrative and fictional-to write, and who had thrown a party for Charlotte Lennox when her first novel, Harriot Stuart, came out.

In and of itself, a negative response to a scholarly work is not beyond comprehension, nor is a critical work's disappearance from the literary scene. Certainly male critics met with rejection. ${ }^{7}$ None of them, however, met with the consistency that female critics' work received. Lennox's groundbreaking archival study, for example, was routinely rejected. Farmer mentions "the ingenious Mrs. Lenox" [sic] only once by name, and agrees with her conclusions two other times without crediting her for them (163, 166). Edward Capell's 1767 edition of Shakespeare's plays ignored her work altogether. Johnson barely alluded to Shakespear Illustrated, either with or without its title, in his own collected Shakespeare (Small 186-187; Franklin, Shakespeare Domesticated 229; Doody, "Shakespeare's Novels" 296). When George Stevens re-issued Johnson's "Notes on Shakespeare's Plays" in 1773, he removed a paragraph in which Johnson admits he obtained information from Lennox, allowing Johnson to take credit for the scholarship (Johnson 310). The Isaac Reed (1785 [Nelsen 141]), Malone (1790), and Boswell-Malone (1821) editions followed suit. Both Malone and Boswell listed Lennox among Shakespeare scholars, but without further comment (Small 203). Ultimately, eighteenth- and nineteenth-century editors and commentators simply let it slip into obscurity, and the twentieth century has seconded the motion. When it is acknowledged, Shakespear Illustrated evidently offers proof only of dreadful literary judgment.

Furthermore, although one might argue that these female authors' creative work was simply better than their critical work, "better" is precisely the term in question. What makes it "better" to an eighteenth-century audience seems less the substance of its observations than the form that those observations take. The Female Quixote, for example, attacks romance and the improbabilities it teaches women to enact and expect. Susan Green, Jonathan Brody Kramnick, and Margaret Anne Doody see the same agenda in Shakespear Illustrated. Both texts comment on the use of romance as a discourse for constructing femininity and its use as a form of female discourse, and both texts reveal the inadequacy of romance and its ultimate futility for this project (Green; Kramnick; Doody, "Shakespeare's Novels").

There is nothing new to the idea that some authors successfully engaged with certain subjects and genres while other authors did not, and as Kathryn Shevelow points out, the increasing access of women to print culture as readers, writers, and 
the objects of representation did not inevitably result in "enfranchisement and inclusion," but rather created a more ambivalent set of norms and conventions that worked equally as agents of "restriction and containment" (1). If eighteenth-century women were pushed into using unconventional discourses for their criticism, then we must look elsewhere for it. As The Female Quixote and Ellen Gardiner both suggest, one site for that criticism is the novel.

Conventions can be gendered; readers can learn to associate sets of conventions and, ultimately, genres with certain genders, and can resist accepting works that defy their expectations. Some discourses can serve, therefore, as alternative methods of expression for authors marginalized or excluded from other discourses. Which came first, the novel as critical form or the exclusion of women from conventional criticism? As criticism and the novel became increasingly professionalized and therefore increasingly defined, and defined differently, women's criticism eschewed discourse for narrative not because or not only because women preferred the novel, but also because readers preferred women to use it. This theory certainly explains what happened to Lennox, Montagu, and Griffith's work, which does not defy the content or method of Shakespeare criticism at the moment that these women wrote, but instead strikingly conforms to them. When women critics used the scholarly conventions of criticism, their work was unacceptable; as women they were not part of the group associated with those conventions. If they abjured the scholarly conventions of criticism, they also abjured the appearance of writing criticism. As Gardiner notes, "society's perception of their novels as private discourse results in this criticism paradoxically becoming a private matter altogether" (150). In other words, women authors produced novels that criticized but not criticism.

Lennox, Montagu, and Griffith's texts and histories reveal much about the development of an eighteenth-century critical canon, and enhance our understanding of how rhetoric served as a mechanism for segregating forms of discourse during the eighteenth century. In addition, these works under- score that the development of the novel in the eighteenth century should be seen not simply as the creation of a public voice for authors previously silenced, but also as the creation of an alternative form of criticism. While this understanding of the novel as criticism may be nothing new to readers of either century, it is time to use that understanding to recover women's criticism, conventionally discursive or un-conventionally narrative, from the obscurity in which their own time and ours have cast it.

\section{Notes}

${ }^{1}$ James Fitzmaurice observes that "what Cavendish has to say about Shakespeare is strikingly modern and quite out of keeping with the time in which Sociable Letters was published" (xvii).

${ }^{2}$ For a more extensive discussion of Shakespeare's rise to stardom, see Michael Dobson, The Making of the National Poet: Shakespeare, Adaptation, and Authorship, 1660-1769 (Oxford: Clarendon Press, 1992); Simon Jarvis, Scholars and Gentlemen: Shakespearian Textual Criticism and Representations of Scholarly Labour, 1725-1765 (Oxford: Clarendon Press, 1995); or Jean I. Marsden, The Re-Imagined Text: Shakespeare, Adaptation, and Eighteenth-Century Literary Theory (Lexington: U P of Kentucky, 1995).

${ }^{3}$ With five plays produced during her lifetime, three of them successes, there are only four women after 1700 with more plays staged (Rizzo 120-121).

${ }^{4}$ Lanser's explanation of these ideas in Fictions of Autbority can sound somewhat essentialist in their formulation of the rhetorical or discursive norm as male and the deviance as female. Nevertheless, the idea that readers can learn to associate certain discourses-and their attendant conventions-with certain genders and that this association can in turn affect composition, is what is of interest here and holds, regardless of whether an originating discourse or norm is automatically male.

${ }^{5}$ For more discussion of the kind of vitriol employed see Colin Franklin, Shakespeare Domesticated: The Eighteenth-Century Editions (England: Scolar Press, 1991) or Peter Seary, "The Early Editors of Shakespeare and the Judgments of Johnson," Johnson After Two Hundred Years, ed. Paul J. Korshin (Philadelphia: U of Pennsylvania P, 1986).

${ }^{6}$ Kramnick 447. Both Franklin (Shakespeare Domesticated, 229) and Small (187) recognize that Johnson used Shakespear Illustrated's Dedication to isolate the views propounded in the work that follows. Neither critic, however, recognizes as Kramnick does that the opposition of Dedication and Shakespear Illustrated represents a clash of ideologies and aesthetics.

${ }^{7}$ William Warburton and others obscured many of Thomas Hanmer's views by taking credit for them, and Hanmer's notes on a 
difficult passage created an avalanche of criticism that "completely obliterated" his contribution (Dash 277-278, 274, 275-276). Later, by depicting Lewis Theobald as "weak, ignorant, mean, faithless, petulant, and ostentatious," Samuel Johnson discredited his predecessor and Theobald's views (Seary, "Lewis Theobald" 106).

\section{Works Cited}

Argyros, Ellen. '“Intruding Herself into the Chair of Criticism': Elizabeth Griffith and The Morality of Shakespeare's Drama Illustrated." Eighteenth-Century Women and the Arts. Ed. Frederick M. Keene and Susan E. Lorsch. Connecticut: Greenwood, 1988. 283-289.

Belanger, Terry. "Publishers and Writers in Eighteenth-Century England." Books and Their Readers in Eighteenth-Century England. Ed. Isabel Rivers. New York: St. Martin's, 1982. 525.

Binns, J.W. "Some Lectures on Shakespeare in Eighteenth-Century Oxford: The Praelectiones poeticae of William Hawkins." Shakespeare: Text, Language, Criticism. Essays in Honour of Marvin Spevack. Ed. Bernhard Fabian and Kurt Tezeli von Rosador. New York: Olms-Weidmann, 1987. 19-33.

Boswell, James. Journal of a Tour to the Hebrides with Samuel Johnson, LL.D., 1773. Ed. Frederick A. Pottle and Charles H. Bennett. New York: McGraw-Hill, 1963.

Busse, John. Mrs Montagu, Queen of the Blues. Pennsylvania: Folcroft Library Editions, 1977.

Cavendish, Margaret. Sociable Letters. Ed. James Fitzmaurice. New York: Garland, 1997.

Dash, Irene. "When the Culture Obtrudes: Hanmer's Winter's Tale." Reading Readings: Essays on Shakespeare Editing in the Eighteenth Century. Ed. Joanna Gondris. Madison: Associated U P, 1998. 268-280.

Dobson, Michael. The Making of the National Poet: Shakespeare, Adaptation, and Authorship, 1660-1769. Oxford: Clarendon, 1992.

Doody, Margaret Anne. Introduction to The Female Quixote, or, The Adventures of Arabella. Ed. Margaret Dalziel. New York: Oxford U P, 1989. xi-xxxii.

"Shakespeare's Novels: Charlotte Lennox Illustrated." Studies in the Novel 19.3: 296-310.

Farmer, Richard. "An Essay on the Learning of Shakespeare: Addressed to Joseph Craddock, Esq." Eighteenth-Century Essays on Shakespeare. Ed. D. Nichol Smith. Oxford: Clarendon, 1963. 151-202.

Fielding, Henry. The Covent-Garden Journal. Number 24 (March 24, 1752). The Covent-Garden Journal and a Plan of the Universal Register-Office by Henry Fielding. Ed. Bertrand A. Goldgar. Connecticut: Wesleyan U P, 1988. 154-161.
Fitzmaurice, James. Introduction. Sociable Letters. Ed. James Fitzmaurice. New York: Garland, 1997. xi-xxi.

Franklin, Colin. "Print and Design in Eighteenth-Century Editions of Shakespeare." The Book Collector 43.4: 517-528.

- Shakespeare Domesticated: The Eighteenth-Century Editions. England: Scolar, 1991.

Gardiner, Ellen. Regulating Readers: Gender and Criticism in the Eighteenth-Century Novel. Newark: U of Delaware P, 1999 .

Green, Susan. "A Cultural Reading of Charlotte Lennox's Shakespear Illustrated." Cultural Readings of Restoration and Eighteenth-Century English Theater. Ed. J. Douglas Canfield and Deborah C. Payne. Athens: U of Georgia P, 1994. 228-257.

Griffith, Elizabeth. The Morality of Shakespeare's Drama Illustrated. London: T. Cadell, 1775.

Haywood, Eliza. From The Female Spectator, Book VIII (1745), ii, 90-93. Shakespeare: The Critical Heritage. Vol. 3: 17331752. Ed. Brian Vickers. Boston: Routledge \& Kegan Paul, 1975. 162-164.

Jarvis, Simon. Scholars and Gentlemen: Shakespearian Textual Criticism and Representations of Scholarly Labour, 17251765. Oxford: Clarendon, 1995.

Kramnick, Jonathan Brody. "Reading Shakespeare's Novels: Literary History and Cultural Politics in the Lennox-Johnson Debate." Modern Language Quarterly 55.4: 429-453.

Lanser, Susan Sniader. Fictions of Autbority: Women Writers and Narrative Voice. Ithaca: Cornell U P, 1992.

Lanser, Susan Sniader and Evelyn Torton Beck. "[Why] Are There No Great Women Critics? And What Difference Does It Make?" The Prism of Sex: Essays in the Sociology of Knowledge. Ed. Julia A. Sherman and Evelyn Torton Beck. Wisconsin: U of Wisconsin P, 1979. 79-91.

Lennox, Charlotte. Shakespear Illustrated: or the Novels and Histories, On which the Plays of Shakespear Are founded. Collected and Translated from the Original Authors. 3 vols. New York: AMS, 1973.

Levin, Kate. “'The Cure of Arabella's Mind': Charlotte Lennox and the Disciplining of the Female Reader." Women's Writing: The Elizabethan to Victorian Period 2.3: 271-290.

Marsden, Jean I. The Re-Imagined Text: Shakespeare, Adaptation, and Eighteenth-Century Literary Theory. Lexington: U P of Kentucky, 1995.

Montagu, Elizabeth. "An Essay on the Writings and Genius of Shakespeare, Compared with the Greek and French Dramatic Poets. With Some Remarks upon the Misrepresentations of Mons. de Voltaire." 6th edition. An Essay on the Writings and Genius of Shakespeare, Compared with the Greek and French Dramatic Poets. With Some Remarks 
upon the Misrepresentations of Mons. de Voltaire. To which are added, Three Dialogues of the Dead. London: Harding and Wright, 1810. New York: AMS, 1966. v-264.

Rev. of The Morality of Shakespeare's Drama Illustrated by Elizabeth Griffith. The Critical Review Vol. XXXIX (March 1775): 203-209.

Rev. of The Morality of Shakespeare's Drama Illustrated by Elizabeth Griffith. The Monthly Review Vol. LII (June 1775): 465-468.

Morgann, Maurice. "An Essay on the Dramatic Character of Sir John Falstaff." Eighteenth-Century Essays on Shakespeare. Ed. D. Nichol Smith. Oxford: Clarendon, 1963. 203-283.

Rizzo, Betty. “'Depressa Resurgam': Elizabeth Griffith's Playwriting Career." Curtain Calls: British and American Women and the Theater, 1660-1820. Ed. Mary Anne Schofield and Cecilia Macheski. Athens: Ohio U P, 1991. 120-142.

Rowe, Nicholas. "Some Account of the Life, etc., of Mr. William Shakespeare." Eighteenth-Century Essays on Shakespeare. Ed. D. Nichol Smith. Oxford: Clarendon, 1963. 1-22.

Runge, Laura L. Gender and Language in British Literary Criticism, 1660-1790. Cambridge: Cambridge U P, 1997.

Seary. Peter. "The Early Editors of Shakespeare and the Judgments of Johnson." Johnson After Two Hundred Years. Ed. Paul J. Korshin. Philadelphia: U of Pennsylvania P, 1986. 175186.

. "Lewis Theobald, Edmund Malone, and Others." Reading Readings: Essays on Shakespeare Editing in the Eighteenth Century. Ed. Joanna Gondris. Madison: Associated U Ps, 1998. 105-122.

Shevelow, Kathryn. Women and Print Culture: The Construction of Femininity in the Early Periodical. New York: Routledge, 1989.

Small, Miriam Rossiter. Charlotte Ramsay Lennox: An Eighteenth Century Lady of Letters. New Haven: Yale U P, 1935.

Smith. D. Nichol. Introduction. Eighteenth-Century Essays on Shakespeare. Ed. D. Nichol Smith. Oxford: Clarendon, 1963. xi-lxii.

Theobald, Lewis. Mr. Shakespeare restored: or, a Specimen of the Many Errors, as well Committed, or Unamended, by Mr. Pope in his Late Edition of this Poet. Designed Not only to correct the said Edition, but to restore the True Reading of Shakespeare in all the Editions ever yet publish'd. London: R. Franklin, J. Woodman and D. Lyon, and C. Davis, 1726.

Walsh, Marcus. Shakespeare, Milton, and Eighteenth-Century Literary Editing: The Beginnings of Interpretative Scholarship. Cambridge: Cambridge U P, 1997.

Warton, Joseph. Essay \#93 in The Adventurer. Tuesday, September 25, 1753. Volume the Second. London: J. Payne, 1754.
Essay \#97 in The Adventurer. Tuesday, October 9, 1753. Volume the Second. London: J. Payne, 1754.

- Essay \#113 in The Adventurer. Tuesday, December 4, 1753. Volume the Second. London: J. Payne, 1754.

- Essay \#116 in The Adventurer. Saturday, December 15, 1753. Volume the Second. London: J. Payne, 1754.

—. Essay \# 122 in The Adventurer. Saturday, January 5, 1754. Volume the Second. London: J. Payne, 1754.

Whalley, Peter. An Enquiry into the Learning of Shakespeare, With Remarks on Several Passages of his Plays. In a Conversation between Eugenius and Neander. London: T. Waller, 1748.

Woolf, Virginia. A Room of One's Own. New York: Harcourt, Brace, 1929. 